\section{Studia}

\section{z Filologii Polskiej i Słowiańskiej}

DOI: $10.11649 /$ sfps.1653
Studia z Filologii Polskiej i Słowiańskiej, 54

Warszawa 2019

Article No. 1653

Citation:

Żak, A. (2019). O pewnym szczególe z wilamowskiej fonetyki próba analizy w kontekście arealnym. Studia z Filologii Polskiej i Słowiańskiej, 54. https://doi.org/10.11649/sfps.1653

\author{
Andrzej Żak \\ (Uniwersytet Warszawski)
}

\title{
O pewnym szczególe $z$ wilamowskiej fonetyki - próba analizy w kontekście arealnym
}

\section{Wilamowszczyzna i Wilamowice. Metodologia}

Wilamowszczyzna jest zagrożoną wymarciem germańską odmianą językową (ang. language variety), którą posługuje się ok. 20 rodzimych użytkowników w miasteczku Wilamowice k. Oświęcimia (woj. śląskie, pow. bielski). Są to prawie wyłącznie osoby starsze. Wilamowice (wil. Wymysoü, nm. Wilmesau) stanowią germańską wyspę językową na polskojęzycznym terytorium. Mieszkańcy miasteczka posługują się systemem, który w literaturze określany był dawniej jako „narzecze wilamowickie” (Młynek, 1909), „niemiecki dialekt z Wilamowic" (Kleczkowski, 1920; Lasatowicz, 1992; Mojmir, 1930, 1936), „etnolekt wilamowski” (np. Wicherkiewicz, 1998) czy wreszcie ,język wilamowski” (np. Andrason, 2014; Olko, Wicherkiewicz, \& Borges, 2016). Użytkownicy wilamowszczyzny swoją mowę określają najczęściej jako wymysiöeryśy śpröh 'język wilamowski'. W literaturze anglojęzycznej popularność zdobyło ostatnie określenie, co ma zapewne związek z coraz większym zainteresowaniem

This is an Open Access article distributed under the terms of the Creative Commons Attribution 3.0 PL License (creativecommons.org/licenses/by/3.0/pl/), which permits redistribution, commercial and non-commercial, provided that the article is properly cited. (c) The Author(s) 2019.

Publisher: Institute of Slavic Studies, Polish Academy of Sciences

[Wydawca: Instytut Slawistyki Polskiej Akademii Nauk] 
badaczy wilamowszczyzną i próbami jej rewitalizacji (szerzej o tym zob. Olko i in., 2016). Jeśli zaś chodzi o pochodzenie wilamowskiego, to poglądy badaczy na ten temat są dość rozbieżne. Ostatnio przyjmuje się, że wilamowszczyzna wywodzi się z dialektów środkowoniemieckich, morfologia wykazuje cechy typowo śląskie (przegląd literatury na ten temat daje Wicherkiewicz, 2013). Wśród mieszkańców miasteczka dominuje natomiast pogląd, iż ich przodkowie przybyli z terenów dzisiejszej Flandrii czy nawet Szkocji lub Anglii, co określić można jako mitologię pochodzenia, związaną najprawdopodobniej $\mathrm{z}$ negatywnymi konotacjami etnonimu Niemiec.

Artykuł dotyczy występowania w wilamowszczyźnie glajdu [w] i jego pochodzenia $\left(<[\mathrm{l}]<{ }^{*} l\right)$. Wpływ polszczyzny na występowanie $[\mathrm{w}](<[\mathrm{l}])$ w wilamowskim był zaznaczany w literaturze (Andrason, 2014, s. 6, 2015, s. 68; Ritchie, 2012, ss. 39-40; por. też Kleczkowski, 1920, ss. 125-126, który sugeruje wpływ polski na występowanie [w] w innym (już wymarłym) germańskim dialekcie wyspowym - szynwałdzkim ${ }^{1}$ ), nikt jak dotąd nie podjął się jednak poszerzonej arealno-typologicznej analizy tego zjawiska. Niniejszy artykuł ma na celu tę lukę wypełnić. Przejście ${ }^{\star} l>[1]>[\mathrm{w}]$ w wilamowskim zostanie porównane $\mathrm{z}$ analogicznymi zmianami $\mathrm{w}$ polskim języku literackim $\mathrm{i}$ jego dialektach oraz w niemieckim języku literackim i jego dialektach. Omawiana zmiana jest uwarunkowana artykulacyjnie i występuje w różnych językach świata. Wilamowski doświadczył bardzo silnego kontaktu z językiem polskim, na poziomie nie tylko fonetyki, lecz także morfologii, składni czy leksyki (por. np. Andrason, 2014, 2015; Żak, 2016). Celem artykułu jest próba odpowiedzi na pytanie, na ile zmiana ta może być wynikiem kontaktu wilamowskiego z polszczyzną.

\section{Wilamowska fonetyka ([1] i [w]). Stan badań}

Współczesna fonetyka wilamowska jak dotąd nie doczekała się szczegółowego i wyczerpującego opracowania. Pierwsze dokładniejsze opracowania (Kleczkowski, 1920; Młynek, 1909) powstały około stu lat temu, siłą rzeczy więc nie odpowiadają w pełni używanemu dzisiaj w Wilamowicach systemowi. Niniejszy artykuł dotyczyć będzie jednej różnicy, zauważalnej po porówna-

\footnotetext{
1 Szynwałd (nm. Schönwald) - dziś Bojków, dzielnica Gliwic.
} 
niu opisu Kleczkowskiego (Kleczkowski, 1920) z dzisiejszym stanem wiedzy. Chodzi o występowania glajdu [w], który zastąpił welaryzowaną lateralną spółgłoskę [1] ${ }^{2}$ (kontynuant śrwn. /l/).

U Kleczkowskiego (Kleczkowski, 1920, s. 121) można przeczytać, że w wilamowskim zachodniogermańskie ${ }^{*} l$ daje właściwie we wszystkich pozycjach $<\nmid>$ (tj. w nagłosie, śródgłosie i wygłosie, a także niezależnie od tego, czy znajduje się w początkowej części sylaby, czy w jej kodzie). Wyjątkami są (Kleczkowski, 1920, ss.122-124; Ritchie, 2012, ss. 37-40):

1. pozycja po tzw. samogłoskach palatalnych (powstałych w wyniku przegłosu z samogłosek szeregu przedniego), np. àlf 'jedenaście' (por. nm. elf), fäld 'pole' (por. nm. Feld), hàlik święty' (por. nm. heilig), hel 'jasny' (por. nm. hell);

2. pozycja po ${ }^{\star} r$ (które zanikło w śródgłosie), np. feljyn 'stracić' (por. nm. verloren);

3. pozycja po [J] i [c] ${ }^{4}$, np. fłygl 'skrzydło' (por. nm. Flügel);

4. pozycja przed [J] [c], np. gywylk 'chmura' (por. nm. Wolke);

5. deminutywny sufiks -la przed welarnymi, np. bjyk-la 'brzoza-DEM';

6. niektóre zapożyczenia, np. àltan 'altana', seler 'seler'.

Ritchie (Ritchie, 2012, ss. 37-40) opisuje dystrybucję [1] i [w] jako komplementarną, twierdząc, że [l] występuje jedynie w sufiksie -la (pozycyjny wariant sufiksu -ła) i w nielicznych zapożyczeniach. Nie jest to jednak prawda w wilamowskim można znaleźć co najmniej jedną parę minimalną ${ }^{5}$, różniącą się omawianymi głoskami: löda 'lody' (zapożyczenie z pol. lody) : łöda 'włosy', co świadczy o fonemiczności /l/ i /w/. Ponadto, inaczej niż twierdzi Ritchie, występowanie [1] nie ogranicza się jedynie do sufiksu -la i kilku zapożyczeń, a zależy także od kontekstu (palatalna vs. niepalatalna), co odpowiada opisowi przedstawionemu przez Kleczkowskiego. Ritchie (Ritchie, 2012, ss. 39-40) jednak trafnie zauważa, że wokalizacja $[\mathrm{l}]>[\mathrm{w}]$ zachodzi właściwie niezależnie od pozycji w sylabie i tym samym przypomina sytuację w polszczyźnie ${ }^{6}$.

2 [1], w odróżnieniu od tzw. jasnego [l], nazywane jest czasem ciemnym (por. Crystal, 2008, s. 128).

${ }^{3}$ Jeśli nie zaznaczono inaczej, wilamowskie przykłady zapisywane są według ortografii T. Króla, stosowanej najczęściej w publikacjach naukowych i literackich.

${ }^{4} \mathrm{Na}$ temat występowania [J] i [c] w wilamowskim por. Andrason \& Król, 2016, ss. 17-18.

${ }^{5}$ Spostrzeżenie to autor zawdzięcza T. Królowi.

${ }^{6}$ Por. też Andrason, 2014, s. 6. 
Głoska < > opisywana jest przez Kleczkowskiego jako „czysto spółgłoskowa” i „niezgłoskotwórcza”, taka sama jak literackie polskie $<$ ł $>$ (Kleczkowski, 1920, s. 13). Kleczkowski wyraźnie przy tym zaznacza, iż nie chodzi o „niezgłoskotwórczą pełnogłoskę”. O „polskiej wymowie” <ł> wcześniej wspomina także Młynek (Młynek, 1909, s. 12). Jak się wydaje, chodzi tu więc o spółgłoskę boczną, przedniojęzykowo-zębową, welaryzowaną [1]. Warto zauważyć, że o welarnej wymowie /l/ wspominają też Lasatowicz (Lasatowicz, 1992, s. 52) i Wicherkiewicz (Wicherkiewicz, 2003, s. 406) w kontekście twórczości wilamowskiego poety Floriana Biesika (1850-1926).

Z dostępnych opisów, potwierdzonych prowadzonymi od 2013 r. przez autora niniejszego artykułu badaniami wilamowszczyzny, wynika, iż we współczesnym wilamowskim najczęstszym kontynuantem śrwn. /l/ jest tylny wysoki glajd [w] (Andrason \& Król, 2016, s. 14; Ritchie, 2012, ss. 37-40). W najnowszej ortografii, opracowanej przez T. Króla i stosowanej w ostatnich wilamowskich utworach literackich i tekstach naukowych, zapisywany jest on za pomocą grafemu $<\nmid>$. Dźwięk ten może występować niezależnie od pozycji w sylabie i słowie, por.

1. na początku (ang. onset) sylaby, w tym w nagłosie słowa, np. ława 'żyć' (por. nm. leben), tiw 'miły, kochany' (por. nm. lieb), łoüt 'ludzie' (por. nm. Leute), kłop 'mężczyzna, mąż' (por. pol. dial. kłop 'mężczyzna, mąż);

2. w pozycji interwokalicznej, np. àmałik 'pomału' (zapożyczenie z pol. (po)mału?), foła 'upaść' (por. nm. fallen);

3. w kodzie (ang. coda) sylaby, w tym w wygłosie słowa, np. ábysła 'trochę', śłöfa 'spać' (por. nm. schlafen), möł 'raz' (por. nm. Mal), ołd 'stary' (por. nm. alt).

Nietrudno się więc zorientować, że $<\nmid>$ odpowiada w większości przypadków germańskiemu (niemieckiemu) $<\mathrm{l}>[\mathrm{l}]^{8}$ bądź - w zapożyczeniach $\mathrm{z}$ polszczyzny - polskiemu $<\nmid>$ (na temat wartości fonetycznej pol. $<\nmid>$ por. niżej).

Wynika z tego, że w ciągu stu lat, które minęły od publikacji Kleczkowskiego, wilamowski przeprowadził zmianę $[1]>[\mathrm{w}]$, często określaną w literaturze jako wokalizacja $l^{9}$. Można ponadto byłoby przypuszczać, że zmiana $[\mathrm{f}]>[\mathrm{w}]$ zaszła

7 -ła jest sufiksem deminutywnym.

8 Por. np. Wängler, 1976, s. 40, tablica nr 12.

9 Kleczkowski (Kleczkowski, 1920, s. 124) wspomina co prawda o wokalizacji <ł> [1] w wilamowskim, jednak obejmuje ona jedynie nieliczne leksemy. 
w wilamowskim stosunkowo niedawno. Pewną wskazówkę stanowią nagrania T. Wicherkiewicza z 1989 r., na których w mowie użytkowników wilamowszczyzny najstarszego pokolenia (urodzonych na przełomie XIX i XX wieku) wyraźnie słychać wymowę przedniojęzykowo-zębową [1]. Jak się wydaje, ostatnim użytkownikiem, u którego taka wymowa występowała, był mężczyzna urodzony w 1918 r. Nagrania sporządzone przed jego śmiercią (2011 r.) udostępnił autorowi niniejszego artykułu T. Król ${ }^{10}$. Dziś jednak u wszystkich znanych użytkowników wilamowskiego występuje glajd [w], który jest produktem wokalizacji [1].

\section{Język polski i jego dialekty}

Dawnej polskiej literackiej wymowie, o której wspomina Kleczkowski (Kleczkowski, 1920, s. 13), odpowiadała tzw. wymowa przedniojęzykowo-zębowa. Była to więc głoska [ł] (zapisywana jako $<\nmid>$ ), którą można opisać jako ustną, boczną, przedniojęzykowo-zębową, dźwięczną, welaryzowaną (ta ostatnia cecha nie jest zwykle explicite nazywana w opisach polszczyzny, na rentgenogramach widoczne jest jednak wyraźne unoszenie się tylnej części grzbietu języka ku velum - por. np. Wierzchowska, 1967, s. 103). Wiadomo także, że wargi przy artykulacji [1] mają skłonność do zaokrąglania się (nie obserwuje się tego np. przy [l]). Drugi formant $\left(\mathrm{F}_{2}\right)$ waha się natomiast w granicach $800-900 \mathrm{~Hz}$ (dla porównania: dla głoski [l] $\mathrm{F}_{2}$ wynosi ok. $1400 \mathrm{~Hz}$ ). Jak wiadomo, niska wartość $\mathrm{F}_{2}$ świadczy o zwężeniu kanału głosowego w okolicy velum, co może być spowodowane przesunięciem się języka ku górze i wysklepieniem jego grzbietu (Dłuska, 1986, ss. 129-130, 102-103; Jassem, 1964, s. 339; Wierzchowska, 1967, ss. 35-36; Wiśniewski, 2007, s. 62).

W dzisiejszej polszczyźnie [1] ${ }^{11}\left(<\right.$ psł. ${ }^{*}$ ) ma charakter ustępujący. Głoska ta wymawiana jest jedynie na niektórych terenach (zwłaszcza na wschodnich kresach) i - coraz rzadziej - w tzw. wymowie scenicznej, por. Dukiewicz \& Sawicka, 1995, s. 39; Mazur, 1981, ss. 359-360). U większości użytkowników współczesnej polszczyzny w kontekstach, w których dawniej pojawiało się [1],

10 Zarówno jemu, jak i T. Wicherkiewiczowi za udostępnienie swoich nagrań autor serdecznie dziękuje.

${ }^{11}$ A także fakultatywny wariant bezdźwięczny [1]], występujący po bezdźwięcznej lub w obustronnym sąsiedztwie bezdźwięcznych. 
dziś występuje glajd (półsamogłoska) $[\mathrm{w}]^{12}$ (oznaczana w polskich (slawistycznych) opracowaniach fonetycznych przeważnie jako [u]). Jest to głoska dźwięczna, ustna, tylna i labialna. Jej artykulacja przypomina artykulację samogłoski [u]: masa języka przesuwa się ku tyłowi, wyokrągla ku górze, przewężając kanał ustno-gardłowy w okolicach velum. To ostatnie przywiera do tylnej ściany jamy gardłowej (Dłuska, 1986, s. 116; Wierzchowska, 1967, s. 114; Wiśniewski, 2007, ss. 86-88).

Dla literackiej odmiany języka polskiego przyjmuje się następujący rozwój: ${ }^{*} l>[\mathrm{l}]>[\mathrm{w}]^{13}$. Ostatnia zmiana $([\mathrm{H}]>[\mathrm{w}])$, nazywana w polskiej tradycji lingwistycznej wałczeniem, żywa jest od końca XVI w. (por. np. Dejna, 1993, s. 115; Dubisz, 1994; a także Zwoliński, 1949), choć jej ślady można chyba znaleźć nawet w czternastowiecznych zabytkach. W Kazaniach świętokrzyskich czy pierwszej części Psatterza floriańskiego obok form typu mołwić, mołwa (ps. ${ }^{*}$ molv-, por. np. czes. mluva, mluviti; ros. молвá, мо́лвить) pojawiają się także formy typu mowić, mowa (współczesne pol. mówić, mowa), wiązane z synkopą glajdu ${ }^{14}$ (np. Łoś, 1922, s. 143, podobnie też Długosz-Kurczabowa \& Dubisz, 2006, s. 111; Kamińska, 1981, s. 84), a więc z przejściem [1] > [w] > $\varnothing($ mołwa $>$ mouwa $>$ mowa $)$. Jest to jednak przypadek izolowany. Co warte podkreślenia, przejście [1] $>$ [w] w polszczyźnie jest niezależne od pozycji, por. pol. ładny [wadni], łaska [waska], pływać [pwiIvatc], była [bıwa], mała [mawa], pył [pıw], chodził [xodziw].

Przedniojęzykowo-zębowa wymowa [1] trzyma się jednak (czy przynajmniej trzymała się do połowy ubiegłego stulecia) w pasie pogranicza wschodniego i południowego (prawdopodobnie pod wpływem sąsiednich języków słowiańskich), a wyspowo także na Mazowszu bliskim, w Małopolsce i na pograniczu małopolsko-wielkopolskim (Dejna, 1993, s. 115, mapa nr 8; Nitsch, 1957, ss. 46-47; Urbańczyk, 1981, s. 32). W kontekście wilamowszczyzny należałoby się przyjrzeć występowaniu [ł] na zachodnich peryferiach dialektu małopolskiego i we wschodniej części areału śląskiego, ponieważ te dialekty - jak wiadomo (Andrason, 2014; Żak, 2016, s. 141) - wchodziły z wilamowskim w silny kontakt. Dzisiaj w okolicach Wilamowic nie notuje się jednak [1]. Głoski tej

12 I odpowiednio [w] w miejsce [t].

13 Wyjątek mógłby tu stanowić jedynie słowiński i część północnej kaszubszczyzny (w której występuje tzw. bylaczenie), gdzie - według niektórych badaczy - nigdy nie zaszła zmiana psł. ${ }^{*} l>$ [l] (Dejna, 1993, s. 114). Spotykane są tam więc formy typu bél 'był'.

${ }^{14}$ Inaczej na ten temat Petrus', 1947. 
nie zauważyła Zieniukowa (Zieniukowa, 1998, ss. 200-201), która prowadziła badania we wsiach dookoła Wilamowic, ani Żak (Żak, 2016, ss. 133-134), notujący kilka dialektalnych cech polskich, występujących w mowie mieszkańców miasteczka. Także wcześniejsze opracowania (Dejna \& Gala, 2001, mapa nr 36) pokazują, że na polskim areale językowym w okolicach Wilamowic występuje jedynie glajd [w]. Zanotowany on został w punkcie Głębowice (gm. Osiek; ok. $13 \mathrm{~km}$ na północny wschód od Wilamowic, obszar występowania dialektu małopolskiego) i w Rudzicy (gm. Jasienica, ok. $20 \mathrm{~km}$ na południowy zachód od Wilamowic, areał śląski). Wskazówką co do dziewiętnastowiecznej polskiej wymowy w okolicach Wilamowic może być uwaga Kosińskiego (Kosiński, 1891, s. 10) o występowaniu w Pisarzowicach wargowego $ł$ (zapisywanego jako $<w>$ ), chodzi więc tu najprawdopodobniej o glajd [w]. Opisywana przez Kosińskiego wieś Pisarzowice jest o tyle ciekawa, że znajduje się właściwie pomiędzy dwoma germańskimi wyspami językowymi (Wilamowicami i Bielsko-Białą).

Brak przejścia $[\mathrm{H}]>[\mathrm{w}]$ zanotowano natomiast w miejscowości Koniaków (gm. Istebna; ok. $40 \mathrm{~km}$ od Wilamowic na południe) i Stonawa w Czechach (ok. $45 \mathrm{~km}$ na południowy zachód), co może potwierdzać uwagę Nitscha (Nitsch, 1957, ss. 46-47), iż [1] spotykane jest w części Śląska przyległej do obszaru morawskiego. Ponadto należy odnotować, że izofona zmiany [1] > [w] przebiega blisko obszaru, na którym występują bądź występowały w przeszłości germańskie wyspy językowe (Wilamowice, Bielsko-Biała, por. Dejna, 1993, s. 115, mapa nr 8).

\section{Język niemiecki i jego dialekty}

W standardowym języku niemieckim [1] nie ulega welaryzacji i wokalizacji (por. np. Wängler, 1976, s. 40). W kontekście wilamowskiego jednak najbardziej interesujące są bliskie mu geograficznie i genetycznie niemieckie dialekty Śląska (por. Ritchie, 2012, ss. 83-84), istniejące w większości do końca II wojny światowej. Pewnych danych na ich temat dostarcza niżej cytowany Schlesischer Sprachatlas (Günter, 1967, dalej SchlSA). Trzeba jednak zauważyć, że materiał ujęty w SchlSA był zbierany różnymi metodami w różnym czasie: zdania Wenkera (Wenkersätze) uzyskane metodą korespondencyjną w latach siedemdziesiątych XIX w., wywiady z użytkownikami śląskich dialektów mieszkającymi w Niemczech czy badania terenowe na potrzeby atlasu. Sprawia to, że interpretacja materiału staje się trudniejsza - szczególnie w przypadku 
fonetyki, gdzie metoda korespondencyjna oczywiście nie może dać wiarygodnych rezultatów. Mimo to w analizowanym materiale można zauważyć pewne prawidłowości, a mianowicie - występowanie welaryzowanego [1] na Śląsku ograniczało się do trzech (mniej lub bardziej) zwartych obszarów. Pierwszy z nich tworzy wertykalną linię wyznaczoną miastami: Crossen (Krosno Odrzańskie) ${ }^{15}$, Freystadt (Kożuchów), Sorau (Żary), Kohlfurt (Węgliniec), Lauban (Lubań), Gerlachsheim (Grabiszyce). Drugi można zaobserwować między Trachenberg (Żmigród) a Oels (Oleśnica). Trzeci natomiast skupia się między Ziegenhals (Głuchołazy) a Neustadt (Prudnik), pojedyncze przypadki występowania [1] zanotowano także w Schönau (Szonów) koło Leobschütz (Głubczyce) i w Stubenseifen (Stř́brnice, Czechy) koło Mähr (Staré Město, Czechy). Nie można wreszcie nie zauważyć, że wiele przykładów z welaryzowaną notuje SchlSA (Günter, 1967) w Alzen (Hałcnów) ${ }^{16}$, miejscowości należącej dawniej do bielsko-bialskiej wyspy językowej (nm. Bielitz-Bialaer Sprachinsel), a więc leżącej kilkanaście kilometrów od Wilamowic. W tym miejscu należy podkreślić, że omówione wyżej niemieckie dialekty Śląska (poza hałcnowskim) dziś już nie istnieją (istniały mniej więcej do końca II wojny światowej; być może część dawnych użytkowników do dziś posługuje się nimi w Niemczech).

Wokalizacja [1] natomiast (będąca najczęściej konsekwencją jego wcześniejszej welaryzacji, a więc [l] $>[1]>[w]$ ) występuje w wielu niemieckich dialektach, w szczególności na zachodnich i wschodnich peryferiach niemieckiego obszaru językowego (np. w dialektach okolic Poznania, w jednym wyspowym (?) dialekcie na słowackim Spiszu), a także w dolnoniemieckim dialekcie Vierlande (Besch, Knoop, Putschke, \& Wiegand, 1983, ss. 1111-1112; von Essen, 1964, ss. 53-54; Kleczkowski, 1920, ss. 125-126). Przejście [1] > [w] tłumaczone jest czasem wpływem sąsiednich języków: na zachodzie romańskim (francuskim), na wschodzie słowiańskim (polskim). Jeśli chodzi o niemieckie dialekty Śląska, to wokalizacja [1] zachodzi na obszarze morawskim, w okolicach Glogau (Głogów) i w szynwałdzkim. Wszędzie jednak ograniczona jest ona kontekstowo. Ogólnie rzecz biorąc, zachodzi wyłącznie w kodzie (ang. coda)

15 Na pierwszym miejscu podane są nazwy niemieckie, w nawiasie - współczesne nazwy polskie.

${ }^{16}$ W Hałcnowie do dzisiaj mieszka kilka osób pamiętających dawną mowę. Z obserwacji autora, który od 2015 r. prowadzi tam badania, wynika, iż najczęściej występującą lateralną jest tzw. neutralne $l[1]$, sporadycznie jednak może się pojawiać i [1]. Por. też Dolatowski (Dolatowski, 2017, s. 65) o możliwości występowania w przeszłości wokalizacji [1] w hałcnowskim. 
sylaby (por. przykłady: hell [hew] 'jasny', Tal [ta:w] 'dolina', Schule [Jow] 'szkoła'), bardzo rzadko - w jej początkowej części (np. Sohle [zวwə] 'podeszwa, dno') i zupełnie wyjątkowo (i tylko przy bliskim sąsiedztwie słowiańskim) także w nagłosie (np. lang [wan] 'długi', spiskie dialekty na Słowacji). Jedynie (według niektórych danych) w dialektach luksemburskich i dialektach okolic Siebenbürg (Besch i in., 1983, s. 1111) wokalizacja [1] została przeprowadzona w pełnym zakresie (vollständig), jednak późniejsze dane tego nie potwierdzają: wokalizacja [1] zachodzi jedynie w kodzie (typ Salz [zawts] 'sól').

Można więc sądzić, że dane zgromadzone w SchlSA (Günter, 1967) pokazują różne stadia przejścia $[\mathrm{l}]>[\mathrm{l}]>[\mathrm{w}]$, a stopień zaawansowania zmiany, ogólnie rzecz biorąc, jest chyba tym większy, im silniejszy był kontakt z językami słowiańskimi (wyspowy dialekt szynwałdzki, spiskie dialekty na Słowacji).

\section{Artykulacyjna i akustyczna interpretacja wokalizacji [1]. Kontekst typologiczny}

Ogólnie rzec ujmując, istnieją dwie hipotezy na temat wokalizacji [1]: artykulacyjna i akustyczna (von Essen, 1964; Recasens, 2012, ss. 58-59). Pierwsza mówi o utracie zwarcia między dziąsłami a czubkiem języka (por. też Dukiewicz \& Sawicka, 1995, s. 39). Druga hipoteza uwzględnia akustyczne podobieństwo między [1] a [w]: obydwie głoski mają bardzo podobną strukturę formantową (niska wartość $\mathrm{F}_{2}$ - ok. $800-1000 \mathrm{~Hz}^{17}$ ), co świadczy o unoszeniu się przedniej części grzbietu języka podczas artykulacji tych głosek, a także o powstającym wówczas przewężeniu w okolicy tylnej części grzbietu języka i velum. Dla porównania: dla głoski [1] $\mathrm{F}_{2}$ wynosi ok. $1400 \mathrm{~Hz}^{18}$. Ponadto przy artykulacji [1] wargi mają skłonność do zaokrąglania się (tak jak przy artykulacji [w], nie obserwuje się tego natomiast przy [1]). Zauważono także, że [1] wykazuje skłonność do wokalizacji w [w], a tzw. neutralne (jasne) [l] w [i] (von Essen, 1964, s. 58).

Poza wspomnianymi wyżej niemieckimi dialektami, które przeprowadziły kontekstowo uwarunkowaną wokalizację [1], podobne zjawisko występuje

17 Por. też Ohala \& Lorentz, 1977, ss. 581-582.

18 Por. też Dłuska, 1986, ss. 129-130, 102-103; Jassem, 1964, s. 339; Wierzchowska, 1967, ss. 35-36; Wiśniewski, 2007, s. 62. 
w różnych językach Europy, w większości z nich jednak zachodzi jedynie w określonych kontekstach (w zależności od pozycji w sylabie, otoczenia fonetycznego, miejsca akcentu itd., por. Recasens, 2012, s. 57). Przejście [1] > [w] notowane było np. w dialektach angielskich (Hughes \& Trudgill, 1992, ss. 49, 52; Minkova, 2014, ss. 128-131) czy w różnych dialektach romańskich (Recasens, 2012). W tych pierwszych występuje ono w kodzie sylaby (Minkova, 2014, ss. 128-129, por. przykłady: feel [fi:w] 'czuć', cool [ku:w] 'chłodny'). W tych ostatnich natomiast omawiana zmiana następuje w końcowej części sylaby (a więc również w kodzie) przed heterosylabiczną spółgłoską (por. np. alba [,awbo] 'świt', oksytańskie dialekty Gevaudanés), rzadko w pozycji interwokalicznej (jak w części dialektów niemieckich; por. sole [səwi] 'słońce', zachodnie dialekty kampidańskie) czy w wygłosie absolutnym (np. sol [səw] 'słońce', brazylijskie dialekty portugalskiego), Recasens, 2012, ss. 59-6019. Podobne zjawisko (takie jak we wspomnianych wcześniej dialektach angielskich) obserwowane jest także w niektórych językach słowiańskich (ukraiński, białoruski, słoweński, bułgarski, serbsko-chorwacki, por. Dalewska-Greń, 1997, ss. 79-84; Recasens, 2012, s. 59).

\section{Podsumowanie}

1. Dziś w wilamowskim śrwniem. /l/ jest kontynuowane w większości przypadków przez glajd [w]. Przedniojęzykowo-zębowe welaryzowane [1] występowało w wilamowszczyźnie w przeszłości, o czym świadczą dane źródłowe (zwłaszcza Kleczkowski, 1920) i dostępne nagrania. Można by więc przyjąć następujący rozwój fonetyczny dla wilamowskiego: ${ }^{*} l>[1]>[\mathrm{w}]$, identyczny jak w literackiej polszczyźnie (gdzie zmiana ${ }^{*} l>[1]$, rzecz jasna, dokonała się jeszcze w epoce prasłowiańskiej) i większości jej dialektów.

2. Welaryzacja [1], czyli przejście [1] > [1], zachodzi w różnych dialektach niemieckich, $w$ tym w bliskich genetycznie i geograficznie niemieckich dialektach śląskich. W dzisiejszej polszczyźnie praktycznie nie występuje spółgłoska [1] (jest ona kontynuowana przez glajd [w]), natomiast współczesne polskie [1] (i jego kombinatoryjny allofon [K]) kontynuują dawne [li]. Obecność [l] (i nieobecność [1]) w języku polskim sytuuje go w tzw. areale europejskim (Sawicka, 2016, s. 173), razem z m.in. niemieckim, angielskim i niektórymi innymi językami słowiań-

19 Tamże szczegółowa dyskusja przypadków wokalizacji [ł]. 
skimi. Dawna wilamowszczyna i niektóre dialekty niemieckie wykazywałyby w tym względzie podobieństwo do areału wschodniego (do którego zalicza się m.in. cała wschodnia słowiańszczyzna czy języki bałtyckie). Przejście ${ }^{*} l>[1]$ w wilamowskim mogło być spowodowane dawnym polskim wpływem lub chociaż przezeń wzmocnione. Jako paralelę wpływu obcego na barwę lateralnej można by było wskazać litewski. Jak się uważa, pralitewska welarna wymowa /1/ powstała pod wpływem słowiańskim (Zinkevičius, 2006, s. 62).

3. Wokalizacja [l] (czy właściwie [1], czyli przejście [1] $>$ [w]) nigdzie (ani $\mathrm{w}$ dialektach niemieckich ${ }^{20}$, ani w innych wspomnianych wcześniej językach lub dialektach europejskich) nie zachodziła tak konsekwentnie jak w wilamowskim, tj. niezależnie od pozycji w sylabie. Jest to zmiana analogiczna do tej, która zaszła w literackiej polszczyźnie i większości jej dialektów. Rozwój śrwn. /l/ w wilamowskim zależy od kontekstu fonetycznego (palatalny vs. niepalatalny) i w tym względzie także przypomina historyczny rozwój polszczyzny, por. dla polskiego ${ }^{*} l j>\left({ }^{*}\right)>[1]$. Prowadzi to do wytworzenia się dwóch fonemów: /l/ $\mathrm{i} / \mathrm{w} /$, tak samo jak w języku polskim. Rzecz jasna, w polszczyźnie opozycja ta jest o wiele silniej obciążona funkcjonalnie niż w wilamowskim.

Można też przypuszczać, że polskie gwary w okolicy Wilamowic od dłuższego czasu (co najmniej od drugiej połowy XIX wieku) nie znały już [1], w potocznym polskim języku ogólnym także na miejscu [1] występował glajd [w]. Jak zostało już powiedziane, proces ten jest uwarunkowany artykulacyjnie i występuje w językach Europy, jednak paralelność tzw. wałczenia w polszczyźnie i wilamowskiego przejścia $[\mathrm{H}]>[\mathrm{w}]$ każe uznać wpływ polskiego na wilamowski za bardzo prawdopodobny.

4. Głoski $[1]$ i $[w]$ - jako allofony - mogły przez jakiś czas współistnieć w wilamowskich idiolektach. Przerwanie transmisji międzypokoleniowej, szybko postępująca zmiana językowa i w konsekwencji wymieranie wilamowszczyzny spowodowały jeszcze intensywniejszy kontakt z językiem polskim, który najprawdopodobniej przyspieszył omawianą zmianę. Ostatnią znaną osobą, u której zanotowano welaryzowaną spółgłoskową wymowę [1], był mężczyzna urodzony w 1918 r. Najstarsza dziś żyjąca użytkowniczka wilamowszczyzny urodziła się w 1922 r. Można by było zaryzykować twierdzenie, że wokalizacja [1] zaszła w pełni dopiero w ostatnim pokoleniu użytkowników wymysiöeryś.

20 Może jedynie poza spiskim dialektem Chmelnicy (nm. Hopgarten) na Słowacji (por. Valiska, 1967, ss. 38-39) - kwestia ta wymaga dalszych dociekań i weryfikacji. Warto zauważyć, że i tutaj możliwy jest wpływ słowiański. 


\section{Zastosowane skróty}

SchlSA - Schlesischer Sprachatlas (Günter, 1967).

\section{Bibliografia}

Andrason, A. (2014). The Polish component in the Vilamovicean language. Glossos, 12, 1-38. Andrason, A. (2015). Vilamovicean - A Germanic-Slavic mixed language? Studies in Polish Linguistics, 10, 57-85.

Andrason, A., \& Król, T. (2016). A grammar of Wymysorys. Durham, NC: Duke University. Pobrano $\mathrm{z}$ https://slaviccenters.duke.edu/sites/slaviccenters.duke.edu/files/media_items _files/wymysorys-grammar.original.pdf

Besch, W., Knoop, U., Putschke, W., \& Wiegand, H. (Red.). (1983). Dialektologie: Ein Handbuch zur deutschen und allgemeinen Dialektforschung (T. 2). Berlin: de Gruyter. https:// doi.org/10.1515/9783110203332

Crystal, D. (Red.). (2008). A dictionary of linguistics and phonetics. Malden, MA: Blackwell Publishing. https://doi.org/10.1002/9781444302776

Dalewska-Greń, H. (1997). Języki słowiańskie. Warszawa: Wydawnictwo Naukowe PWN.

Dejna, K. (1993). Dialekty polskie. Wrocław: Zakład Narodowy imienia Ossolińskich.

Dejna, K., \& Gala, S. (2001). Atlas gwar polskich: T. 3. Śląsk. Warszawa: Upowszechnianie Nauki-Oświata „UN-O”.

Długosz-Kurczabowa, K., \& Dubisz, S. (2006). Gramatyka historyczna języka polskiego. Warszawa: Wydawnictwa Uniwersytetu Warszawskiego.

Dłuska, M. (1986). Fonetyka polska: Artykulacja głosek polskich. Warszawa: PWN.

Dolatowski, M. (2017). Morphosyntaktische Strukturen des Alznerischen: Versuch einer Rekonstruktion (Praca doktorska). Uniwersytet im. Adama Mickiewicza, Poznań.

Dubisz, S. (1994). Rozwój polskiego systemu fonologicznego. W W. Kupiszewski (Red.), Studia z historii języka polskiego (ss. 9-19). Warszawa: Dom Wydawniczy i Handlowy „ELIPSA”.

Dukiewicz, L., \& Sawicka, I. (1995). Gramatyka współczesnego języka polskiego: Fonetyka i fonologia. Kraków: Wydawnictwo Instytutu Języka Polskiego PAN.

von Essen, O. (1964). An acoustic explanation of the sound shift [1] $>[\mathrm{u}]$ and $[\mathrm{l}]>[\mathrm{i}]$. W D. Abercrombie, D. B. Fry, P. A. D. MacCarthy, N. C. Scott, \& J. L. M. Trim (Red.), In honour of Daniel Jones: Papers contributed on the occasion of his eightieth birthday 12 September 1961 (ss. 53-58). London: Longmans.

Günter, B. (Red.). (1967). Schlesischer Sprachatlas: T. 1. Laut- und Formenatlas [SchlSA]. Marburg: N. G. Elwert.

Hughes, A., \& Trudgill, P. (1992). English accents and dialects: An introduction to social and regional varieties of British English. London: Edward Arnold. 
Jassem, W. (1964). A spectrographic study of Polish speech sounds. W D. Abercrombie, D. B. Fry, P. A. D. MacCarthy, N. C. Scott, \& J. L. M. Trim (Red.), In honour of Daniel Jones: Papers contributed on the occasion of his eightieth birthday 12 September 1961 (ss. 334-348). London: Longmans.

Kamińska, M. (1981). Psałterz floriański: Monografia językowa: Cz. 1. Ortografia, fonetyka, fleksja imion. Wrocław: Zakład Narodowy im. Ossolińskich.

Kleczkowski, A. (1920). Dialekt Wilamowic w zachodniej Galicji: Fonetyka i fleksja. Kraków: Polska Akademia Umiejętności.

Kosiński, W. (1891). Niektóre właściwości mowy pisarzowickiej. Sprawozdania Komisyi Językowéj Akademii Umiejętności, 4, 1-34.

Lasatowicz, M. (1992). Die deutsche Mundart von Wilamowice zwischen 1920 und 1987. Opole: WSP.

Latosiński, J. (1909). Monografia miasteczka Wilamowic na podstawie źródeł autentycznych. Kraków: Drukarnia Literacka.

Łoś, J. (1922). Gramatyka polska: Cz. 1. Głosownia historyczna. Lwów: Zakład Narodowy im. Ossolińskich.

Mazur, K. (1981). O współczesnej polskiej wymowie scenicznej. W H. Kurkowska (Red.), Współczesna polszczyzna. Warszawa: PWN.

Minkova, D. (2014). A historical phonology of English. Edinburgh: Edinburgh University Press.

Młynek, L. (1909). Narzecze wilamowickie [Wilhelmsauer Dialekt. Dy wymmysuaschy Gmoansproch]. Tarnów: J. Pisz.

Mojmir, H. (1930). Wörterbuch der deutschen Mundart von Wilamowice: T. 1. A-R (A. Kleczkowski, Oprac.). Kraków: Polska Akademia Umiejętności.

Mojmir, H. (1936). Wörterbuch der deutschen Mundart von Wilamowice: T. 2. S-Z (A. Kleczkowski \& H. Anders, Oprac.). Kraków: Polska Akademia Umiejętności.

Nitsch, K. (1957). Dialekty języka polskiego. Wrocław: Zakład Narodowy imienia Ossolińskich.

Ohala, J., \& Lorentz, J. (1977). The story of [w]: An exercise in the phonetic explanation for sound patterns. Proceedings of the 3rd Annual Meeting of the Berkeley Linguistic Society, 3, 577-599. https://doi.org/10.3765/bls.v3i0.2264

Olko, J., Wicherkiewicz, T., \& Borges, R. (Red.). (2016). Integral strategies for language revitalization. Warszawa: Wydział Artes Liberales.

Petrus', V. P. (1947). K voprosu o proiskhozhdenii foneticheskoŭ formy leksem pólk i mowa v pol'skom iazyke. Izvestiia Akademii Nauk Soiuza SSR: Otdelenie literatury i iazyka, 6, 51-76.

Recasens, D. (2012). A phonetic interpretation of the sound changes affecting dark /1/ in Romance. W M.-J. Solé \& D. Recasens (Red.), The initiation of sound change: Perception, production, and social factors (ss. 57-75). Amsterdam: John Benjamins Publishing Company. https://doi.org/10.1075/cilt.323.07rec

Ritchie, C. (2012). Some considerations on the origins of Wymysorys (Praca licencjacka). University of Sydney, Department of Linguistics, Sydney.

Sawicka, I. (2016). Na marginesie badań arealnych - barwa słowiańskich lateralnych. W Slavica Onomastica Regionalia: Prace dedykowane Panu Profesorowi Jerzemu Dumie (ss. 169-173). Olsztyn: Wydawnictwo Uniwersytetu Warmińsko-Mazurskiego. 
Urbańczyk, S. (1981). Zarys dialektologii polskiej. Warszawa: PWN.

Valiska, J. (1967). Die zipserdeutsche Mundart von Chmelnica (Hopgarten). Bratislava: Slovenské pedagogické nakladatel'stvo.

Wängler, H.-H. (1976). Atlas deutscher Sprachlaute. Berlin: Akademie-Verlag.

Wicherkiewicz, T. (1998). Uf dyr Wiyrzba zyct yn Zajonc, czyli polskie formy dialektalne w germańskim etnolekcie Wilamowic w dawnym Księstwie Oświęcimskim. W S. Gala (Red.), Teoretyczne, badawcze i dydaktyczne założenia dialektologii (ss. 205-216). Łódź: ŁTN.

Wicherkiewicz, T. (2003). The making of a language: The case of the idiom of Wilamowice, southern Poland. Berlin: de Gruyter. https://doi.org/10.1515/9783110905403

Wicherkiewicz, T. (2013). Pochodzenie języka wilamowskiego - poglądy i badania. Pobrano 11 maja 2019, z http://www.revitalization.al.uw.edu.pl/Content/Uploaded/Documents /wilamowski\%20jezyk\%20-\%20TW-4d5c8ee3-77f0-4807-bde2-9dd0198acc34.pdf

Wierzchowska, B. (1967). Opis fonetyczny języka polskiego. Warszawa: PWN.

Wiśniewski, M. (2007). Zarys fonetyki i fonologii współczesnego języka polskiego. Toruń: Wydawnictwo Naukowe Uniwersytetu Mikołaja Kopernika.

Zieniukowa, J. (1998). Między dialektem a językiem ogólnym: Polszczyzna w gminie Wilamowice na pograniczu Małopolski i Śląska. W S. Gala (Red.), Teoretyczne, badawcze i dydaktyczne założenia dialektologii (ss. 197-203). Łódź: ŁTN.

Zinkevičius, Z. (2006). Lietuvių tarmiu kilmè. Vilnius: Lietuvių kalbos institutas.

Zwoliński, P. (1949). Przejście $\ell \geq u_{\wedge} \mathrm{w}$ języku polskim. Biuletyn Polskiego Towarzystwa Językoznawczego, 9, 81-96.

Żak, A. (2016). The influence of the Polish language on Wymysorys in light of the revitalization process. W J. Olko, T. Wicherkiewicz, \& R. Borges (Red.), Integral strategies for language revitalization (ss. 131-149). Warszawa: Wydział Artes Liberales.

\title{
On a Certain Phonetic Feature of Wymysorys: An Analysis of Areal Aspects
}

\author{
Summary
}

In Wymysorys, also known as Vilamovicean (a Germanic language spoken in Wilamowice, a small town in the south of Poland), velarized laterals [ $\mathrm{t}$ ] have turned into $[\mathrm{w}]$. This shift is characteristic of some Polish and German dialects, although in the latter it only occurs under certain conditions. Since 
Wymysorys displays a strong influence of Polish in many other respects, this change is more likely to have stemmed from contact with Polish.

\section{O pewnym szczególe $z$ wilamowskiej fonetyki - próba analizy w kontekście arealnym}

\section{Streszczenie}

W wilamowskim welaryzowane [1] (kontynuant średnio-wysoko-niemieckiego $l$ ) przeszło $\mathrm{w}$ glajd $[\mathrm{w}]$. Zmiana ta charakterystyczna jest dla różnych języków Europy, w tym dla polszczyzny i niektórych dialektów niemieckich (w tych ostatnich jednak zachodzi jedynie w pewnych warunkach). Silny wpływ polskiego na wilamowski (obserwowany nie tylko w fonetyce) uprawnia do stwierdzenia, iż omawiana zmiana jest wynikiem oddziaływania polszczyzny i dokonała się w ostatnim pokoleniu użytkowników wilamowszczyzny.

Keywords: areal phonetics; Wymysorys; lateral consonants; velarized [1]; glide [w]; Polish language; Polish dialects; German dialects

Słowa kluczowe: fonetyka arealna; język wilamowski; spółgłoski lateralne; welaryzowane [1]; glajd [w]; język polski; dialekty polszczyzny; dialekty niemieckie

Andrzej Żak, University of Warsaw, Warsaw

ORCID: https://orcid.org/0000-0001-6107-989X

Correspondence: andzejus.zakas@gmail.com

The preparation of this article was financed by the author.

Competing interests: The author declares that he has no competing interests. 